\title{
Climate change effects on hydrometeorological compound events over southern Norway
}

\author{
Benjamin Poschlod $^{\text {a,*, Jakob Zscheischler }}{ }^{\mathrm{b}, \mathrm{c}}$, Jana Sillmann ${ }^{\mathrm{d}}$, Raul R. Wood ${ }^{\mathrm{a}}$, Ralf Ludwig ${ }^{\mathrm{a}}$ \\ ${ }^{\text {a }}$ Department of Geography, Ludwig-Maximilians-University Munich, Luisenstr. 37, 80333, Munich, Germany \\ ${ }^{\mathrm{b}}$ Climate and Environmental Physics, University of Bern, Sidlerstrasse 5, 3012, Bern, Switzerland \\ ${ }^{\mathrm{c}}$ Oeschger Centre for Climate Change Research, University of Bern, 3012, Bern, Switzerland \\ d Center for International Climate and Environmental Research (CICERO), Pb. 1129, Blindern, N-0318, Oslo, Norway
}

\section{A R T I C L E I N F O}

\section{Keywords:}

Compound events

Climate change

Large ensemble

Heavy rainfall

Rain-on-snow

Soil saturation

Norway

\begin{abstract}
A B S T R A C T
Hydrometeorological compound events cause severe economical, societal and environmental damage, but their investigation is difficult as they occur rarely and are multivariate. Here we use 50 high-resolution climate simulations from the single model initial condition large ensemble CRCM5-LE to examine two such compound event types in southern Norway: (1) Heavy rainfall on saturated soil during the summer months (June, July, August, September; SES) and (2) Concurrent heavy rainfall and snowmelt (rain-on-snow; ROS). We compare present-day conditions (1980-2009) with future conditions under a high-emission scenario (2070-2099) and investigate the impact of climate change on the frequency and spatial distribution of SES and ROS events. We find that the probability of occurrence of SES events during the summer increases by 38\% until 2070-2099 over the whole study area. The areas with the highest occurrence probability extend from the west coast into the interior. In contrast, the frequency of ROS is projected to decrease by $48 \%$ on average, largely driven by decreases in snowfall. Moreover, the spatial pattern of ROS are projected to change, with the most frequently affected areas shifting from the west coast towards the inner country. Our study highlights the benefits of single model large ensemble simulations for the analysis of compound events.
\end{abstract}

\section{Introduction}

A recent study of Berghuijs et al. (2019) has shown that most annual maximum floods in Europe are not caused by the highest annual rainfall peaks, but by the co-occurrence of rainfall and snowmelt or rainfall on saturated soil. These findings also hold for southern Norway as the combination of rainfall and snowmelt has resulted in the largest floods, for instance in south-eastern Norway in 1995 and 2013 (Krøgli et al., 2018). Concurrent heavy rainfall and snowmelt can also lead to several types of mass movements such as landslides, debris flow or slush flow. This type of event is often referred to as rain-on-snow (ROS) event. ROS events affect the local climate and hydrology by altering snowmelt, runoff, and soil temperatures and, therefore, it further affects vegetation, wildlife and humans (Cohen et al., 2015; Putkonen and Roe, 2003). Seen globally, ROS events are a relatively rare phenomenon. However, they are often the main flood generating process in high latitudes (Cohen et al., 2015) and mountainous areas (McCabe et al., 2007; Merz and Blöschl, 2003). ROS events are therefore frequently found in the Arctic,
Scandinavia, Canada, Greenland and Spitsbergen (Putkonen and Roe, 2003). In Norway, ROS events typically occur during spring when the snow masses accumulated during the winter have not melted yet but temperature starts to rise (Benestad and Haugen, 2007; Pall et al., 2019).

Heavy rainfall on already saturated soil also regularly causes mass movements in southern Norway, such as landslides and flash floods (Dyrrdal et al., 2018). It leads to saturation excess surface runoff, which is often referred to as Dunne runoff (Zhenghui et al., 2003). In southern Norway, flood hazards and mass movements often severely impact infrastructure, economy, personal property, and may even cause fatalities (Krøgli et al., 2018).

ROS events and heavy rainfall on saturated soil are excellent examples for compound events with often severe consequences. Compound events refer to the combination of multiple drivers and/or hazards that contributes to societal or environmental risk (Zscheischler et al., 2018). The individual contributing variables may not have to reach extreme values, but their joint occurrence may lead to a large impact (Bevacqua et al., 2017). The Intergovernmental Panel on Climate Change (IPCC)

\footnotetext{
* Corresponding author.

E-mail address: Benjamin.Poschlod@lmu.de (B. Poschlod).
} 
has first introduced the term compound events within their Special Report on Managing the Risks of Extreme Events and Disasters to Advance Climate Change Adaptation, stressing the need to further explore the influence of climate change on compound events (Seneviratne et al., 2012).

Compound events are rare and multivariate, and observational data only offer limited coverage and sparse sampling of the corners of a multidimensional space (Hao et al., 2018; Zscheischler et al., 2018). Hence, empirical analyses based on observational data are subject to substantial uncertainties due to the limited amount of available data. Conventional univariate statistical modeling is also not an appropriate method to study compound events, as long as there is any dependence between the contributing variables (Bevacqua et al., 2017; Wahl et al., 2015). Therefore, advanced multivariate methods are often applied to investigate the occurrence of compound events as the modeling of these events is complex (Leonard et al., 2014; Zscheischler and Seneviratne, 2017).

Copula theory and multivariate extreme value theory are frequently used to study compound events (Hao et al., 2018). These approaches can handle different types of dependencies between the contributing variables of compound events and model them together with their marginal distributions (Bevacqua et al., 2017). Nevertheless, in many applications the sample size is very small $(<<1000)$, leading to large uncertainties (Serinaldi, 2013). To overcome the prevailing limitation of small sample sizes, ensembles of climate model simulations can be used to analyze compound events (van den Hurk et al., 2015; Zscheischler and Seneviratne, 2017).

Within this study, we use high-resolution climate simulations from the single model initial-condition large ensemble of the ClimEx project (www.climex-project.org) to investigate two different hydrometeorological compound events in southern Norway and to explore the impact of a changing climate on these events: (1) Heavy rainfall on saturated soil during the summer months (June, July, August, September), which will be referred to as SES events (saturation excess during summer) and (2) Concurrent heavy rainfall and snowmelt, which will be referred to as ROS (rain-on-snow) events. The application of large ensembles of highresolution climate simulations to study compound events is a relatively new approach (van den Hurk et al., 2015; Khanal et al., 2019; Zhou and Liu, 2018) even though they are ideally suited for this task due to their large sample size. The aim of this paper is to examine the probability of occurrence of SES and ROS events to map the spatial patterns and to evaluate the change between the reference period (1980-2009) and the far future (2070-2099) due to a changing climate under strong greenhouse gas forcing.

\section{Data and method}

\subsection{Study area}

The study area covers southern Norway and parts of southwestern Sweden (Fig. 1a). The complex orography of the region is governed by the Scandinavian Mountains (or Langfjella) reaching from the northeast to the southwest (see Fig. 1b), whereas the western coastline is deeply indented by fjords. Southwestern Sweden shows little variation at low altitude.

Generally, three types of precipitation occur in southern Norway: (1) frontal, (2) orographic and (3) convective precipitation (Dyrrdal et al., 2016; Roe, 2005). The west coast is exposed to mainly large-scale frontal precipitation driven by the low pressure systems in the North Atlantic, which induce the biggest part of annual precipitation (Heikkilä et al., 2011). Orography adds up to this, whereby the zone of maximum orographic precipitation is found $50 \mathrm{~km}$ inland (Sandvik et al., 2018; Tjelta and Mamen, 2014) with total annual precipitation above 3000 $\mathrm{mm}$.

As these large weather systems mainly come from the west, the southeastern parts of the country are lee areas and the annual precipitation drops to $300-800 \mathrm{~mm}$. Despite this, the highest hourly rainfall intensities occur in the region around the Oslofjord (Hanssen-Bauer et al., 2015). Convective showers and embedded convective cells within frontal systems can induce intensities of up to $40 \mathrm{~mm} / \mathrm{h}$ with convection mainly occurring during the summer months from June to September (Dyrrdal et al., 2016; Poschlod et al., 2018). Hence, the precipitation amounts and intensities vary significantly within the study area depending on the types of precipitation systems and the orographic exposure.

The range in annual mean air temperature in southern Norway is mainly governed by the distance to the sea as well as the altitude (Hanssen-Bauer et al., 2015). Due to the heat content of the ocean, the mean temperatures are quite mild despite the high latitudes (Tjelta and Mamen, 2014). In southern Norway, they range from $-6{ }^{\circ} \mathrm{C}$ in the mountainous areas up to $8^{\circ} \mathrm{C}$ at the coasts (Hanssen-Bauer et al., 2015). Soil moisture in southern Norway follows a weak seasonal cycle with averages around $0.3 \mathrm{~m}^{3} / \mathrm{m}^{3}$ (Pan et al., 2019) according to remote sensing products (ESA Soil Moisture CCI; Gruber et al., 2019) as well as reanalysis data (ERA-INTERIM; Dee et al., 2011). During winter and spring (December to May) soil moisture is slightly lower than in summer

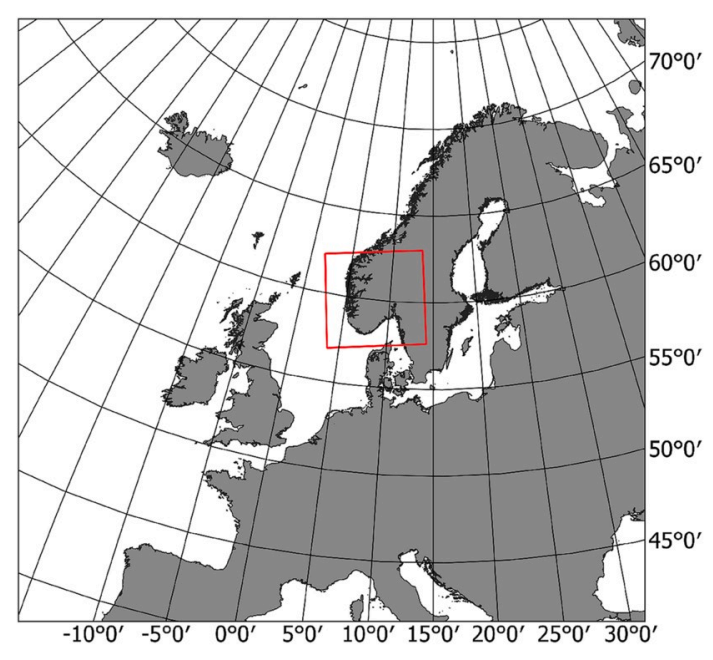

(a)

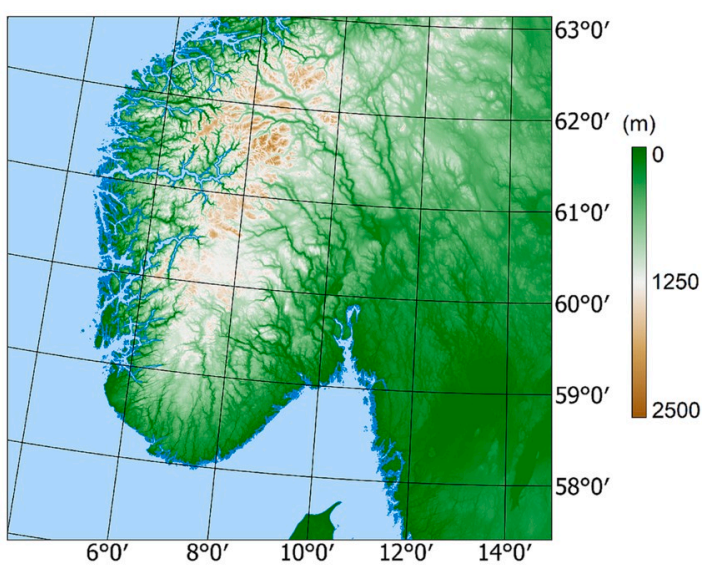

(b)

Fig. 1. (a) Location of the study area over southern Norway. (b) Elevation of the study area. 
and autumn (Naz et al., 2019).

\subsection{Data}

The single model initial-condition large ensemble (SMILE), which is used for this study, was developed within the ClimEx project (Climate change and hydrological extreme events - risks and perspectives for water management in Bavaria and Québec) and is referred to as CRCM5LE. For this dataset, 50 members of the global Canadian Earth System Model (CanESM2) initial-condition large ensemble following the high emission pathway (Representative Concentration Pathway: RCP 8.5) were dynamically downscaled with the Canadian Regional Climate Model (CRCM5) using the EURO-CORDEX grid specifications $\left(0.11^{\circ}\right.$ horizontal resolution) for transient runs from 1950 to 2099, resulting in 7500 years of historic and future climates $(50 \times 150$ years $)$. The Canadian Land Surface Scheme (CLASS, version 3.5; Verseghy, 1991, 2009) is implemented within the CRCM5 setup for the simulation of energy and water fluxes at the surface. CLASS 3.5 allows for a flexible number of soil layers and depth of the layers (Martynov et al., 2013). CLASS integrates the energy and water balances of the land surface forward in time, making use of atmospheric forcing data by the CRCM5 to drive the simulation (Verseghy, 2009). As the simulations are coupled with the CRCM5, the output of surface energy and water fluxes within the CLASS model is passed back to the CRCM5 at each time step. The default configuration of CLASS has been modified applying the ECOCLIMAP formula for bare soil albedo (Masson et al., 2003) and calculating the snow thermal conductivity following Sturm et al. (1997). The total soil moisture content $\left(\mathrm{kg} / \mathrm{m}^{2}\right)$ and surface snow amount $\left(\mathrm{kg} / \mathrm{m}^{2}\right)$ are provided at daily resolution. The model has been successfully applied to simulate soil moisture (Bartlett et al., 2003) and snow amount (Bartlett et al., 2006; Brown et al., 2006; Rutter et al., 2009). Due to the limited data availability for soil moisture and snowmelt, an additional evaluation of the model performance based on specific past events is provided in the Supplementary Material.

The detailed setup of the process chain as well as validation with EOBS data can be found in Leduc et al. (2019) and a comparison to the EURO-CORDEX ensemble is given in von Trentini et al. (2019). The comparison to the E-OBS data for the period between 1980 and 2012 over the whole European domain reveals temperature biases between $-2{ }^{\circ} \mathrm{C}$ and $+2{ }^{\circ} \mathrm{C}$, whereby systematic warm deviations occur mainly in the mountainous regions due to the underrepresentation of the high elevation. For precipitation, the CRCM5 shows a wet bias of 1-2 mm/d, with locally higher biases at the west coasts of most European countries (Leduc et al., 2019).

The domain over southern Norway features $52 \times 49=2548$ grid

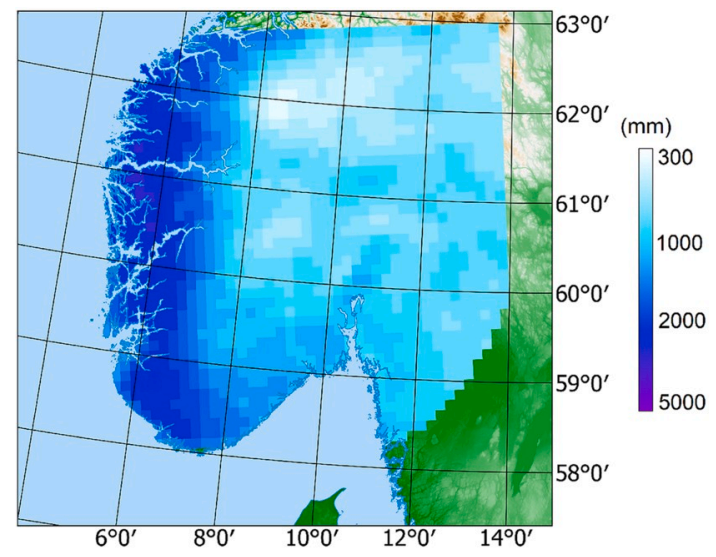

(a) cells, of which 1722 are on land. For this study, apart from validation of air temperature and precipitation, only land grid cells are considered. The time periods of 1980-2009 as well as 2070-2099 are examined as reference and far future periods, respectively.

To validate the simulations of the CRCM5-LE at the regional scale, gridded observational data of precipitation and air temperature in $2 \mathrm{~m}$ height are compared with the climate model data during the 30-year time period between 1980 and 2009. Validation is performed against the $1 \mathrm{~km}$ resolution seNorge 2 data set (Lussana and Tveito, 2017; Lussana et al., 2018), which is first resampled to the CRCM5-LE grid $\left(0.11^{\circ}\right.$, equaling around $12 \mathrm{~km}$ ). The mean annual precipitation totals of the seNorge 2 dataset between 1980 and 2009 as well as the median of the mean annual precipitation totals of the 50 members of the CRCM5-LE are shown in Fig. 2. The CRCM5-LE is able to reproduce the observed spatial patterns of annual precipitation with the highest totals near the west coast (around $50 \mathrm{~km}$ towards the inner country) and the smallest totals at $62^{\circ} \mathrm{N}, 8^{\circ}-9^{\circ} \mathrm{E}$. The areal average of the bias of annual precipitation amounts to $+45 \%$ for the study area. The spatially distributed precipitation bias is presented in Fig. 3a.

In the seNorge2 data undercatch has not been corrected (Lussana et al., 2018). Hence, the data of the rain gauges contain the usual measurement errors of pluviometers resulting from splashing drops, evaporation, wetting and wind effects (Westra et al., 2014). All these factors lead to an undercatch of precipitation. Dyrrdal et al. (2018) assume a total undercatch of up to $10 \%$ for liquid precipitation in Norway. The wind-induced measurement errors regarding solid precipitation can be much higher. Kochendorfer et al. (2017) have found a systematic undercatch of $27 \%$ for a Norwegian site. Additionally to the measurement errors, the spatial distribution of the measuring stations is inhomogeneous with regard to the terrain height as the majority of the measuring stations are located at low altitudes. This leads to an underestimation of (mainly orographically enhanced) precipitation at elevations above $1000 \mathrm{~m}$ a.s.l. For comparison, the evaluation of the EURO-CORDEX ensemble against the $0.25^{\circ}$ spatial resolution E-OBS dataset for the period 1989-2008 reveals a precipitation bias of $25 \%$ averaged over the whole of Scandinavia (Kotlarski et al., 2014). In particular, the regional climate models of EURO-CORDEX have much larger biases over the Norwegian west coast, which are comparable to the results of the CRCM5-LE.

The mean annual temperature of the seNorge 2 dataset and the median of the annual mean temperature of the 50 CRCM5-LE members are shown in Fig. 4. The CRCM5-LE generally reproduces the spatial pattern over the study area, underestimating the air temperature over the mountains and slightly overestimating in the southeast. The areal average of the temperature bias amounts to $-0.20{ }^{\circ} \mathrm{C}$. The spatially

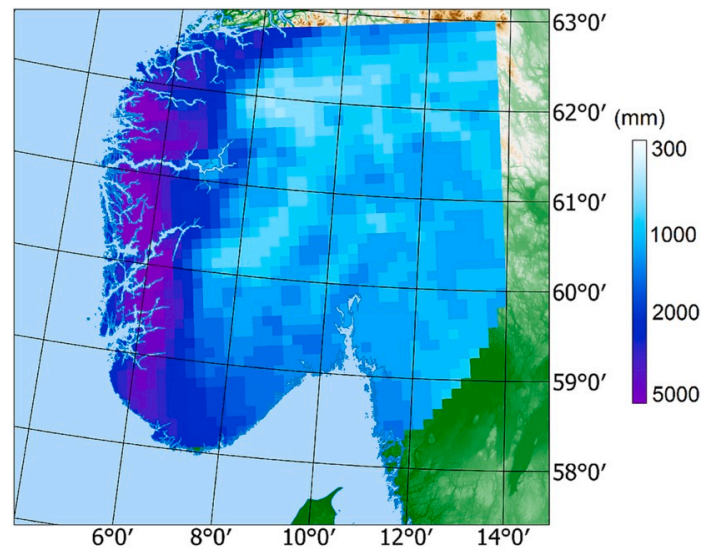

(b)

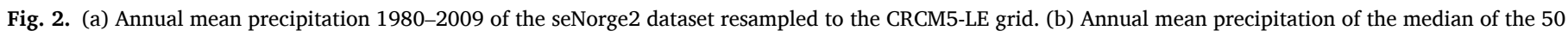
members of the CRCM5-LE. 


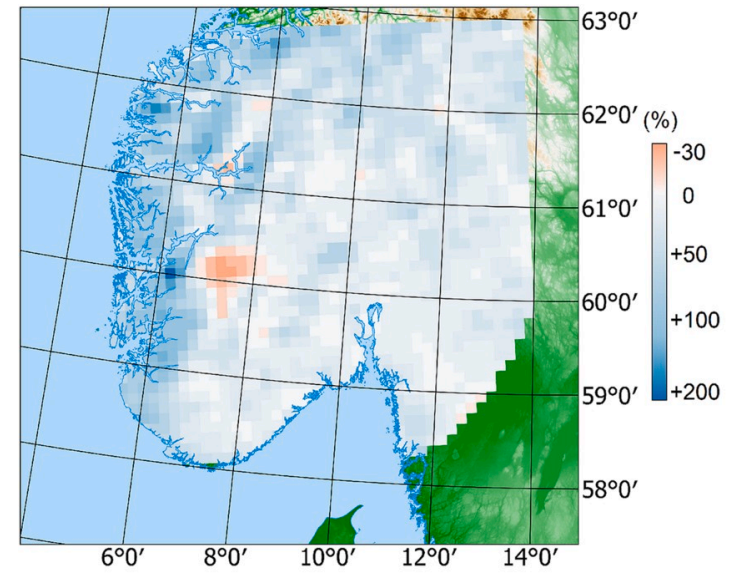

(a)

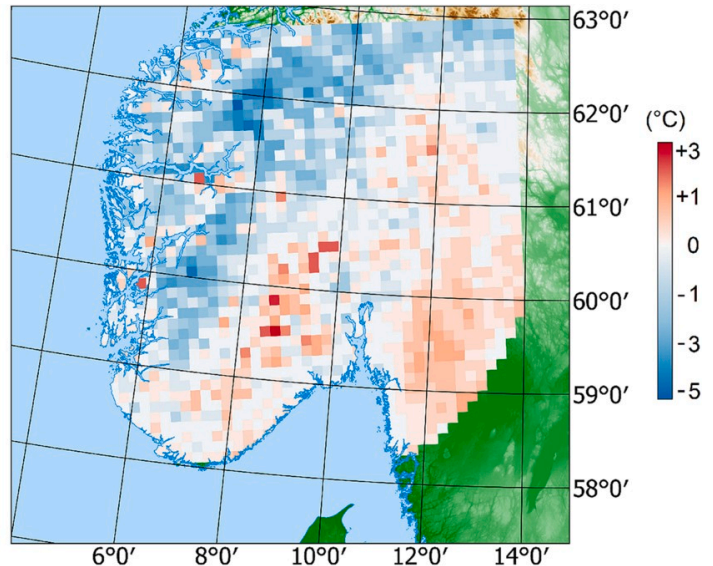

(b)

Fig. 3. (a) Bias of the annual mean precipitation of the median of the 50 members of the CRCM5-LE compared to the seNorge2 dataset in 1980-2009. (b) Bias of the air temperature in $2 \mathrm{~m}$ height.

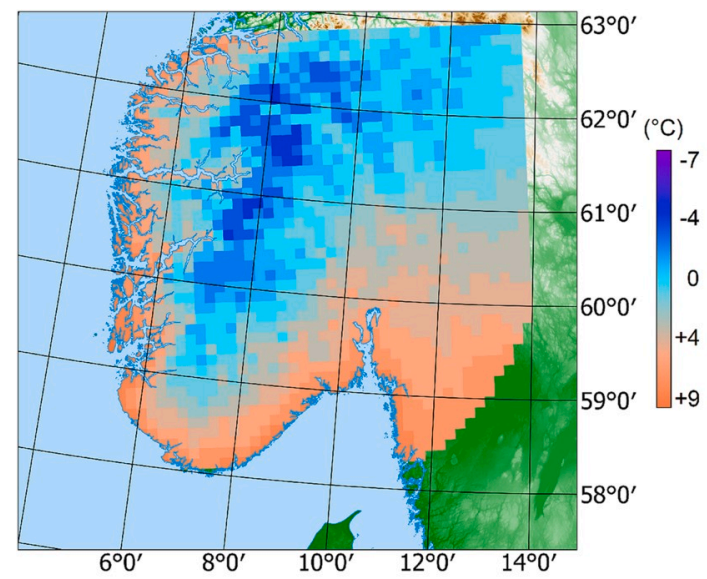

(a)

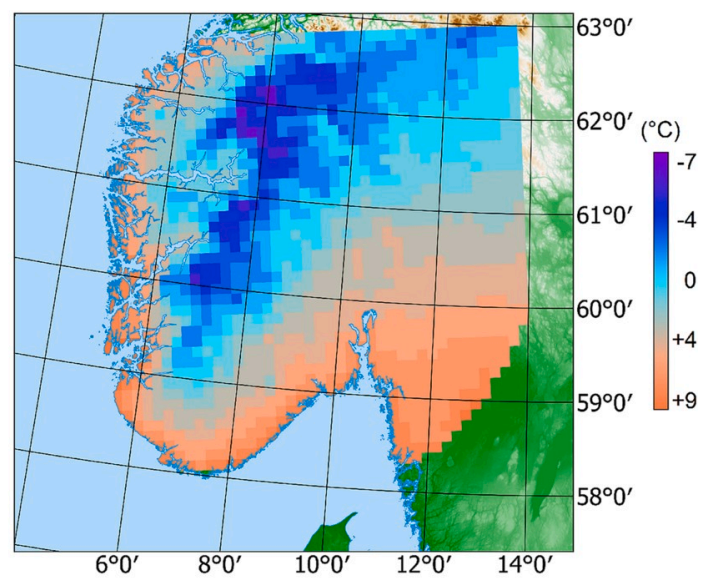

(b)

Fig. 4. (a) Annual mean air temperature in $2 \mathrm{~m}$ height 1980-2009 of the seNorge 2 dataset resampled to the CRCM5-LE grid. (b) Annual mean air temperature of the median of the 50 members of the CRCM5-LE.

distributed bias is presented in Fig. 3b. For comparison, the evaluation of the EURO-CORDEX ensemble against the E-OBS data shows an annual temperature bias of $-0.35^{\circ} \mathrm{C}$ over Scandinavia (Kotlarski et al., 2014). We conclude that the CRCM5-LE performs sufficiently well at reproducing the spatial distribution of precipitation and temperature and that the data are suitable for analyzing the southern Norwegian climate in more detail.

\subsection{Methods}

Because of the uncertainties due to the biases regarding precipitation and temperature, compound events in the CRCM5-LE cannot be defined by absolute thresholds derived from observations. The bias of precipitation and temperature can be corrected if the deviations are not caused by major model errors (Maraun et al., 2017), but would require multivariate bias correction if compound events are to be captured adequately (Zscheischler et al., 2019). Furthermore, for this study, variables apart from precipitation and air temperature will be used, which cannot be bias corrected due to the lack of observations, for instance soil moisture and surface snow amount. We therefore apply a quantile-based approach to investigate the occurrence of compound events. Due to the very low compound exceedance of very high or low quantiles, typically very long time series are required to obtain a sufficiently high number of events for robust statistical analysis (Zscheischler and Seneviratne, 2017). Here we have such conditions by using the CRCM5-LE with its 50 members, delivering a database of 1500 years of climate simulations for each 30 -year period respectively.

We choose the 98th percentile $P_{98}$ for each process contributing to the respective compound event based on the following considerations: The 98th percentile threshold includes the most extreme events in the far tail of the distribution, which are expected to cause the most severe damages, but it includes also relatively moderate extremes, which are impact-relevant as well (Martius et al., 2016; Zhang et al., 2011). Using the data from the CRCM5-LE, this threshold provides a sufficiently large number of samples for a robust statistical assessment of compound events (Schär et al., 2016).

The $P_{98}$ is calculated for each grid cell separately on the basis of the daily data and the respective time period including all 50 members of the CRCM5-LE. The daily sum of liquid precipitation is directly retrieved from the CRCM5-LE variable for each day $d$, whereas the soil moisture content of the previous day $d-1$ is gathered from the CRCM5-LE to account for the soil state before the heavy precipitation event. Given that Norway is not in a dry or transitional climate, the soil is assumed to be very moist or saturated if $P_{98}$ is exceeded. To estimate the amount of 
melting snow for each grid cell at day $d$, we calculated the difference of surface snow amount on day $d-1$ and $d+1$. We define two types of compound events. (1) The SES event is assumed to occur when liquid precipitation and soil moisture exceed their respective $P_{98}$. (2) The occurrence of the ROS event is defined by liquid precipitation and snowmelt exceeding their respective $P_{98}$. Being based on percentiles, the approach is insensitive to any bias in the variable means. The definition of ROS events based on a daily resolved analysis has also been applied by Musselman et al. (2018).

If both processes were independent, the probability of a simultaneous occurrence would be $0.02 \cdot 0.02=0.0004$, or $0.04 \%$. In order to test whether both processes are significantly positively dependent, an independent reference dataset is created for each raster cell. For this, the values for one process variable (liquid precipitation) are randomly shuffled 1000 times and the occurrence probability for the compound event is calculated. A two-sample $t$-test with $1 \%$ significance level is then applied to test whether the re-sampled probability distribution and the original probability distribution of the CRCM5-LE 50 member ensemble originate from the same population. A statistical test with significance level $\alpha$ at $n$ locations would yield $n \cdot \alpha$ locations on average, where the null hypothesis is erroneously rejected, also called false positives
(Ventura et al., 2004). In our case, even the strict significance level of $1 \%$ would lead to $0.01 \cdot 1722=17.22$ false positives on average. We therefore correct the false discovery rate (FDR) (Benjamini and Hochberg, 1995) following Wilks (2016). More specifically, we reject $H_{0}$ at all locations $i$ for which $p_{i} \leq p_{F D R}$, where

$p_{F D R}=\max _{i=1, \ldots, n}\left\{i: p_{(i)} \leq \alpha_{F D R} \cdot\left(\frac{i}{n}\right)\right\}$,

with $p_{(i)}, i=1, \ldots, n$ as the $p$-values of the statistical test sorted in ascending order, $p_{(0)}=0$, and $\alpha_{F D R}=2 \cdot \alpha=0.02$ (Ventura et al., 2004; Wilks, 2016). If the distributions do not originate from the same population and the average probability of occurrence in the CRCM5-LE is higher than in the independent reference data, it is assumed that both processes are positively dependent.

The comparison of the resulting probabilities of compound event occurrence between the present day and the far future period will be carried out in two ways: (1) The 98th percentile of the reference period (1980-2009) $P_{98, \text { ref }}$ is used as threshold for the future period and (2) the 98th percentile is re-calculated for the data of the future period $\left(P_{98}\right.$ fut $)$. The latter variant is a "real" percentile-based method, whereas the first

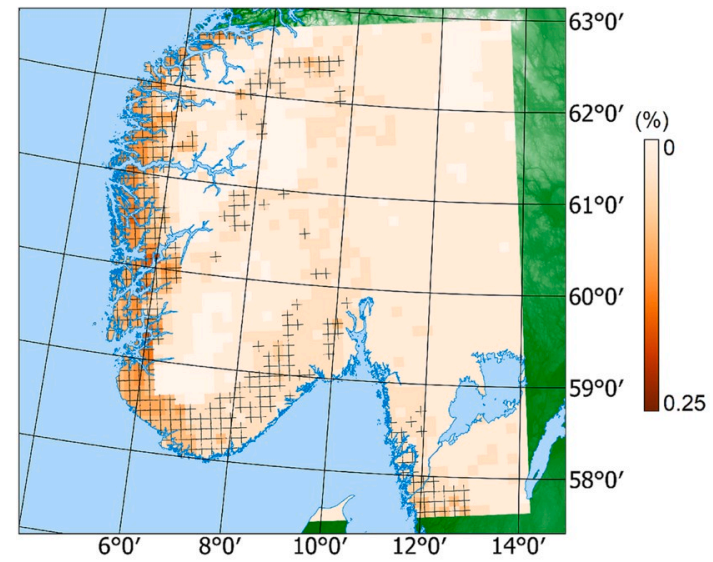

(a)

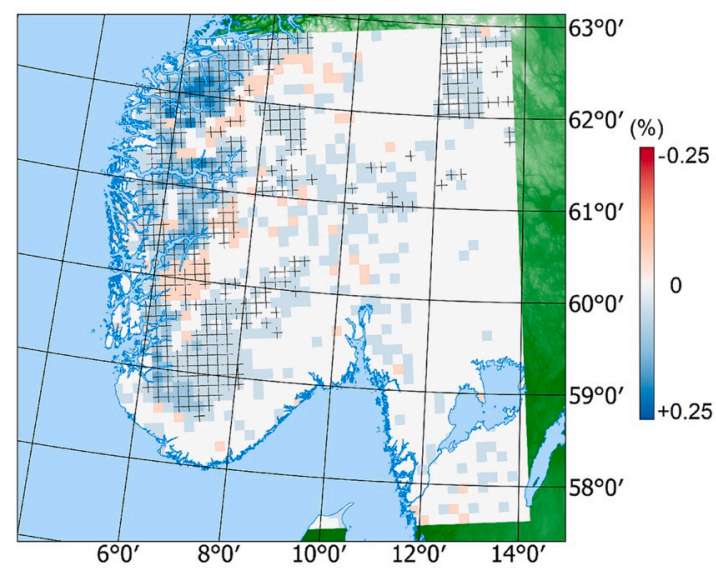

(c)

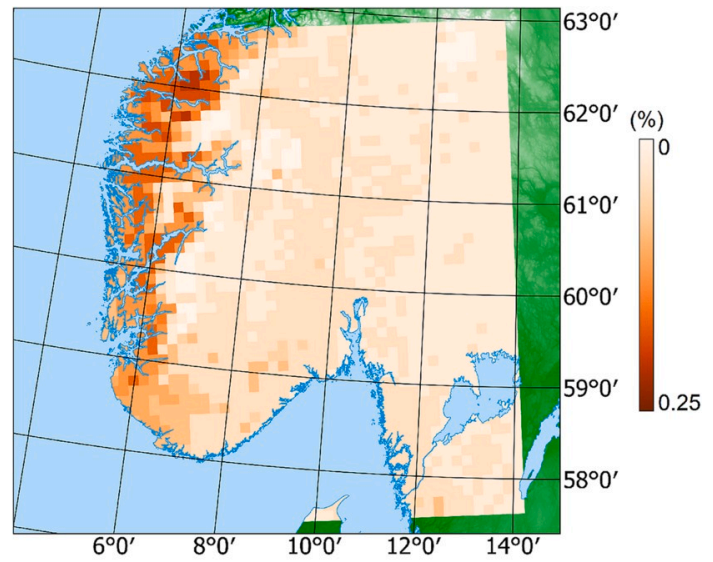

(b)

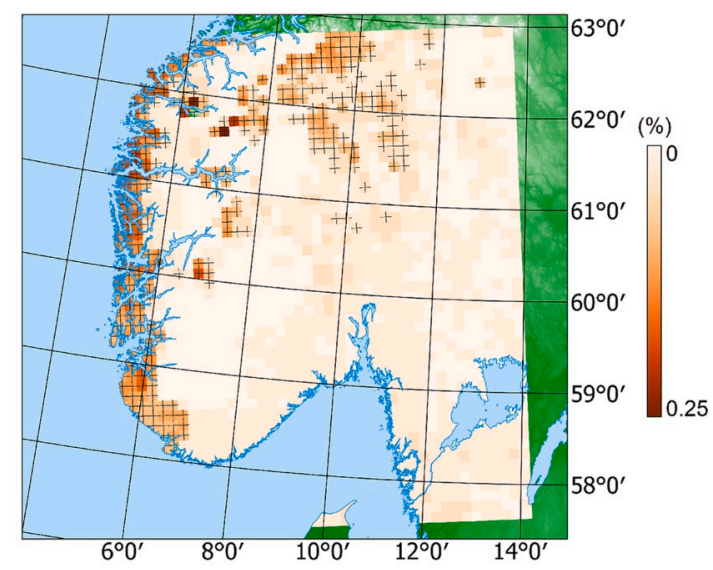

(d)

Fig. 5. (a) Occurrence probability of SES events in the reference period 1980-2009 calculated with the median of the 50 members of the CRCM5-LE and applying $P_{98, r e f}$. Crosses denote regions where the underlying processes are significantly positively dependent $\left(p_{i} \leq p_{F D R}\right)$. (b) Occurrence probability of SES events in the far future period 2070-2099 calculated with the median of the 50 members of the CRCM5-LE and applying $P_{98, \text { ref }}$. (c) Change of the occurrence probability of SES events between the reference period and far future period. Crosses denote regions where the change is significant $\left(p_{i} \leq p_{F D R}\right)$. (d) Occurrence probability of SES events the far future period 2070-2099 calculated with the median of the 50 members of the CRCM5-LE and applying $P_{98 . f u t}$. Crosses denote regions where the underlying processes are significantly positively dependent $\left(p_{i} \leq p_{F D R}\right)$. 
way can be classified as threshold-based (see Schär et al., 2016). The real percentile-based method investigates if the dependence between the two contributing processes will change in the future, whereas the threshold-based method is reflecting the climate change induced trends of the underlying processes (Bevacqua et al., 2019).

\section{Results}

\subsection{Heavy rainfall on saturated soil during summer (SES)}

The daily probability of occurrence of SES events during June-September shows a clear spatial pattern for the 30-year reference period 1980-2009 (Fig. 5a). Near the coastlines (i.e. up to $50 \mathrm{~km}$ inland), the number of compound events is higher than in the rest of the domain. In these areas, the underlying processes are positively dependent, whereas in large parts of the study area, in particular in the Scandinavian Mountains and the eastern inner country, no significant dependence is detected. The areal average of the occurrence probability is $0.041 \%$. The sum of the areal mean of liquid precipitation of the median of the 50 members amounts to $504 \mathrm{~mm}$.

For the analysis applying $P_{98, \text { ref }}$ in the far future, a similar spatial pattern of the SES probability is found, whereby the zone of high probability at the west coast expands inland by up to $70 \mathrm{~km}$ (Fig. $5 \mathrm{~b}$ ). Overall, the occurrence probability of SES events increases by $38.3 \%$ to $0.056 \%$ averaged over the domain. Apart from a decrease in the western areas of the Scandinavian Mountains, the probability of SES events significantly increases in the western parts of the study area, whereby the biggest rise is found in the northwest (Fig. 5c). For large parts in the east and south, no significant changes in the SES frequency can be detected. In the far future of 2070-2099, there is only little change in the amount of rainfall during summer with a total of $526 \mathrm{~mm}(+4.2 \%)$ and a slight decrease of soil moisture $(-4.0 \%)$ due to more evapotranspiration because of higher temperatures. A strong underlying trend in the frequency of intense precipitation significantly increases the number of rainfall events exceeding $P_{98}$,ref by $45.2 \%$.

Applying $P_{98 . f u t}$, the spatial pattern of SES probability (Fig. $5 \mathrm{~d}$ ) is similar to the pattern of Fig. 5a except for an increase of compound events in the northern mountains. Overall, the occurrence probability changes in comparison to the previous method (compare Fig. $5 \mathrm{~d}$ and b). Not only the frequency of heavy rainfall changes, but also the intensity itself, which is why $P_{98}$ fut for daily rainfall in the future period increases by $15.3 \%$ averaged over the domain. The areal average of the occurrence probability of SES events amounts to $0.036 \%$, which means that this average decreases slightly compared to the reference period $(0.041 \%)$. The recalculation of the percentiles based on 2070-2099 $\left(P_{98 . f u t}\right)$ excludes climate change effects on the contributing variables such as more intense precipitation and decreased soil moisture. Comparing Fig. 5a and d therefore highlights changes related to the (temporal) dependence of both contributing processes. Overall, this dependence decreases slightly in large areas at the southern coast and the southeast, resulting in less grid cells where compound events occur due to significant positive dependence of the underlying processes.

In conclusion, the probability of SES events defined by the threshold calculated with the meteorological and soil hydrological conditions of the reference period $\left(P_{98, \text { ref }}\right)$ will increase until 2070-2099 as areal average. The regions with significant increase are located in the west of the study area. The application of $P_{98 . f u t}$ shows only small changes in the probability of occurrence for a major part of the study area. Therefore, we assume that the dependence structure between precipitation and soil moisture does not change significantly compared to the reference period. Hence, we conclude that the changes in Fig. 5b result mainly from the univariate trends in precipitation and soil moisture, respectively.

\subsection{Heavy rainfall and snow-melt (ROS)}

The daily occurrence probability of ROS events is presented in Fig. 6a. Again, there is a strong spatial inhomogeneity with a high number of events near the west coast, the luv side of the Scandinavian Mountains, the Oslofjord and the Swedish west coast, whereas other areas have a very low probability of ROS events. Heavy rainfall in the western and coastal areas is mainly governed by large frontal systems coming from the ocean, which happens throughout the year. Heavy rainfall events in the south of the inner country are more often caused by convective systems during the summer. Hence, the probability of heavy rainfall to occur as amplifier of snowmelt is much higher in the western parts of the area, whereas snowmelting processes in the inner country are often triggered by rising air temperature, which can also cause severe floods (Berghuijs et al., 2019; Rössler et al., 2014). Though, we have to recall that the absolute height of $P_{98}$ for snowmelt is significantly lower at the west coast than in the inner country. The average occurrence probability for the entire domain is $0.037 \%$, which means that the co-occurrence of the processes heavy precipitation and snowmelt is on average slightly less likely than if both processes were totally independent.

Applying $P_{98, \text { ref }}$ on the future period, the spatial distribution changes completely for the Norwegian west coast, and the number of ROS events decreases almost to zero (Fig. 6b). The mountainous regions, some parts of the northern west coast (1-2 grid cells towards the inner country) and the coastal areas around the Oslofjord still show increased probability of ROS events. The strong and significant decrease (see Fig. 6c) is driven by a strong decrease in mean surface snow amount $(-59.2 \%)$ due to higher temperatures. At the west coast, winter temperatures are above $0{ }^{\circ} \mathrm{C}$ for 2070-2099. This effect cannot be fully compensated by the increase of heavy liquid precipitation frequency and intensity. The annual average of liquid precipitation rises from $1117 \mathrm{~mm}$ to $1542 \mathrm{~mm}$ for the study area, and the number of rainfall events greater than $P_{98, \text { ref }}$ increases by $78.3 \%$. Consequently, the areal average of ROS occurrence probability decreases by $47.7 \%$ to $0.019 \%$.

The application of $P_{98 \text { fut }}$ for the future period leads to a different result (Fig. 6d). The spatial pattern is again similar to the pattern from Fig. 6a, except for the increased number of ROS events near the west coast being 1-2 grid cells offset towards the inner country. Due to the decrease in surface snow amount, $P_{98 . f u t}$ decreases by $32.0 \%$ for snowmelt. The 98 th percentile for liquid precipitation increases by $25.7 \%$ on average. The areal mean of the daily occurrence probability amounts to $0.033 \%$.

In summary, the frequency of ROS events exceeding $P_{98, \text { ref }}$ will become significantly lower in the future mainly due to strong decreases of ROS events in the coastal areas. The areal average of ROS event probability for the recalculated $P_{98}$.fut remains on a similar level and shows a spatial distribution analogous to that of the reference period.

\subsection{The effect of internal variability}

The spread of the ensemble distribution can be expressed via the standard deviation (SD). The areal average of the SD for SES event probability increases from $0.030 \%$ during the reference period to $0.037 \%$ for the far future. For ROS event probability, the areal average of the SD decreases from $0.012 \%$ to $0.010 \%$. In order to illustrate this internal variability, the ensemble members with the lowest and highest areal average of occurrence probabilities during the far future period are presented for SES and ROS events in Fig. 7. The lowest occurrence probability for SES events features a similar spatial pattern compared to the median (see Figs. 7a and 5b), whereby the highest SES event frequency is still found near the west coast. The areal average of the SES occurrence probability amounts to $0.022 \%$, which is $46 \%$ lower than the probability of the median of the 50 ensemble members. The most extreme ensemble member shows a totally different spatial distribution 


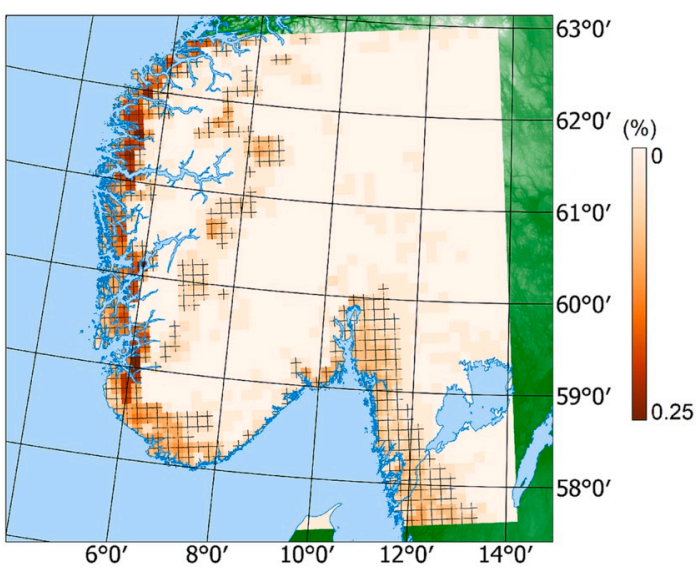

(a)

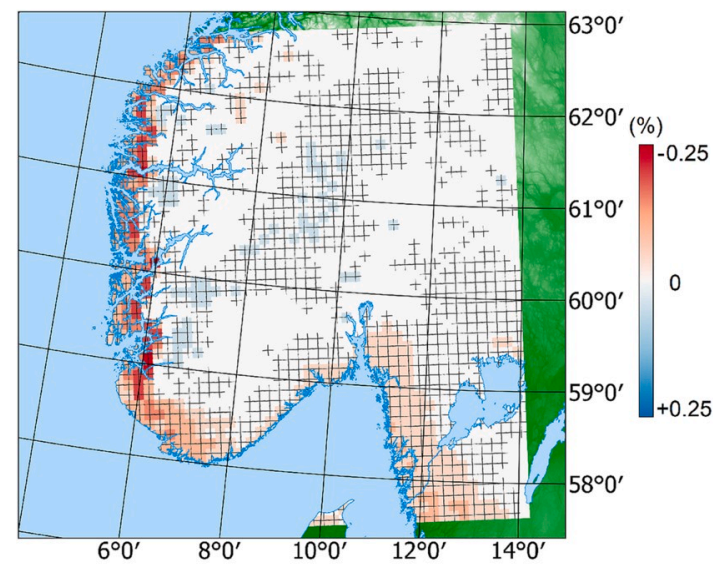

(c)

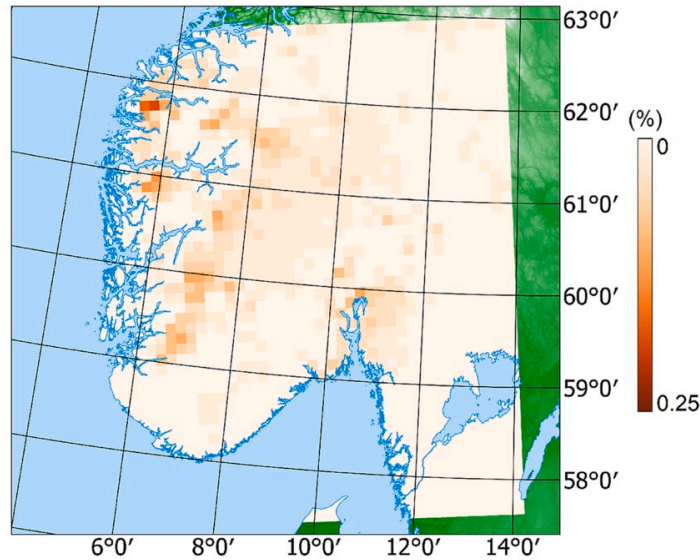

(b)

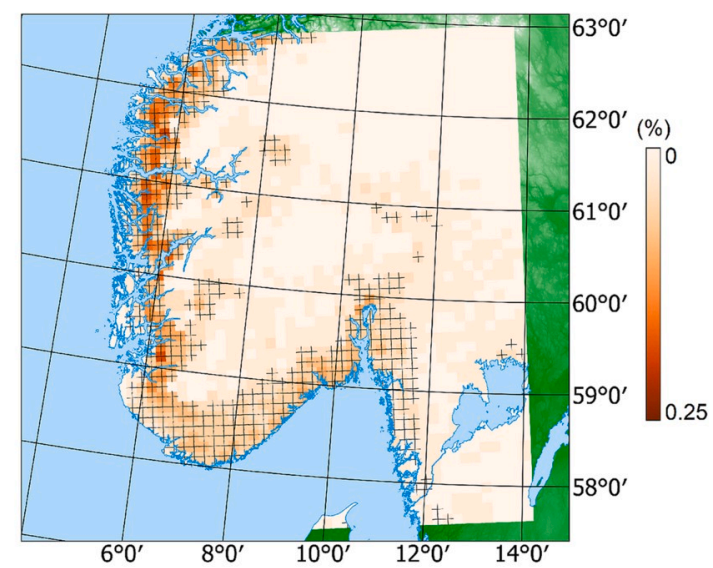

(d)

Fig. 6. (a) Occurrence probability of ROS events in the reference period 1980-2009 calculated with the median of the 50 members of the CRCM5-LE and applying $P_{98, \text { ref }}$. Crosses denote regions where the underlying processes are significantly positively dependent $\left(p_{i} \leq p_{F D R}\right)$. (b) Occurrence probability of ROS events in the far future period 2070-2099 calculated with the median of the 50 members of the CRCM5-LE and applying $P_{98, \text { ref }}$. (c) Change of the occurrence probability of ROS events between the reference period and far future period. Crosses denote regions where the change is significant $\left(p_{i} \leq p_{F D R}\right)$. (d) Occurrence probability of ROS events in the far future period 2070-2099 calculated with the median of the 50 members of the CRCM5-LE and applying $P_{98 . f u t}$. Crosses denote regions where the underlying processes are significantly positively dependent $\left(p_{i} \leq p_{F D R}\right)$.

with high SES event frequency at the west coast, but also in the south and east of the study area (see Fig. 7b), resulting in an areal average of $0.087 \%$ SES occurrence probability. This is $115 \%$ higher than the median probability. The high variability is only partly driven by the variability in the intensity of both contributing variables. The rainfall totals (496 mm and $554 \mathrm{~mm}$; see Fig. 8a) as well as the exceedances of the $P_{98, \text { ref }}$ for liquid precipitation (96 and 114 exceedances within four months of 30 years) differ moderately for both ensemble members. The areal average of soil moisture varies between $805 \mathrm{~kg} / \mathrm{m}^{2}$ and $823 \mathrm{~kg} / \mathrm{m}^{2}$ (see Fig. 8b), whereby 30 and 37 exceedances of the $P_{98, \text { ref }}$ for soil moisture are simulated, respectively. Hence, the wide range of occurrence probabilities for SES events is mainly governed by the variability in temporal coincidence.

For the ROS event, both members with the lowest and highest event probability are presented in Fig. $7 \mathrm{c}$ and $\mathrm{d}$. In comparison to the median of all 50 members, these two members, which represent the upper and lower boundaries of the ensemble, show a smaller variability than the SES events. The respective areal averages amount to $0.0151 \%$ and $0.0279 \%$, which are $21 \%$ lower and $45 \%$ higher than the median probability. Also the spatial distribution of these extreme members as well as the median resemble each other. High ROS event probability is found at the northern west coast, the western flank of the Scandinavian Mountains and around the Oslofjord. The member with the highest ROS event frequency (Fig. 7d) also shows a high event probability in the center and northeast of the study area. The rainfall totals of both members do not differ much (1496 mm and $1548 \mathrm{~mm}$; see Fig. 8c) nor do the number of exceedances of the $P_{98, \text { ref }}$ ( 377 and 396). The amount of snowmelt shows little variation with $425 \mathrm{~mm}$ and $440 \mathrm{~mm}$ (see Fig. 8d) as well as the number of exceedances of the 98th percentile (65 and 71). Therefore, the variability of ROS occurrence probability is also mainly driven by the variability in temporal co-occurrence of rainfall and snowmelt. Hence, we conclude that the internal variability of SES and ROS events occurring is much higher than the variability in the intensity of the driving processes.

\section{Discussion}

Heavy rainfall on already saturated or very moist soil is rarely discussed in studies that investigate the impact of climate change on floodgenerating processes over Scandinavia. Several studies differentiate between rainfall-driven, snowmelt-driven or rainfall and snowmeltdriven floods. The latter category corresponds to the ROS event 


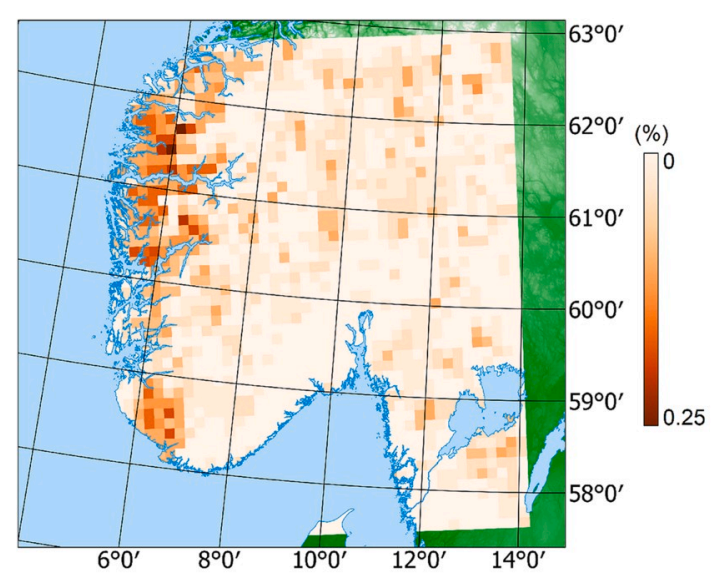

(a)

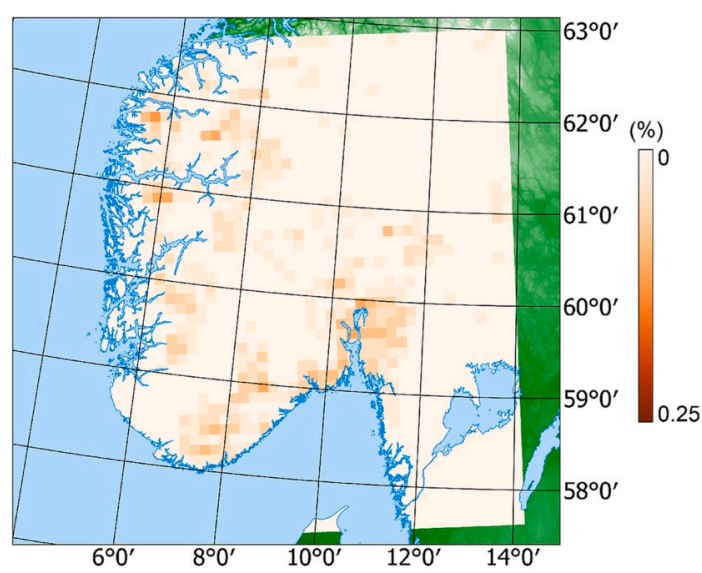

(c)

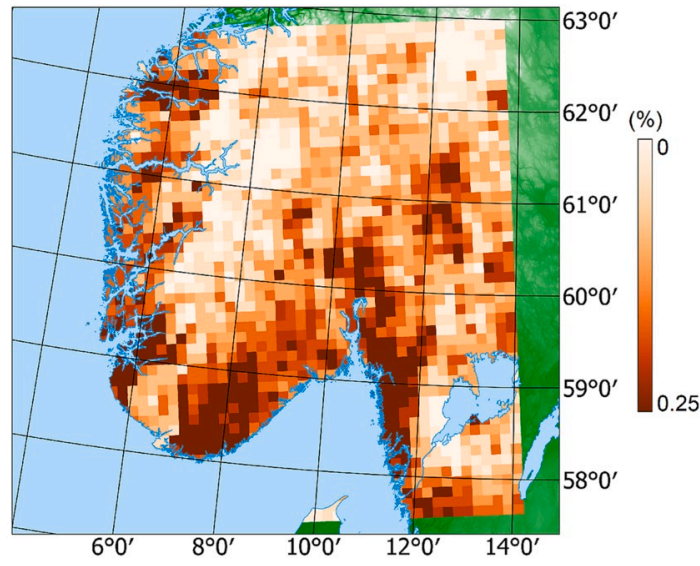

(b)

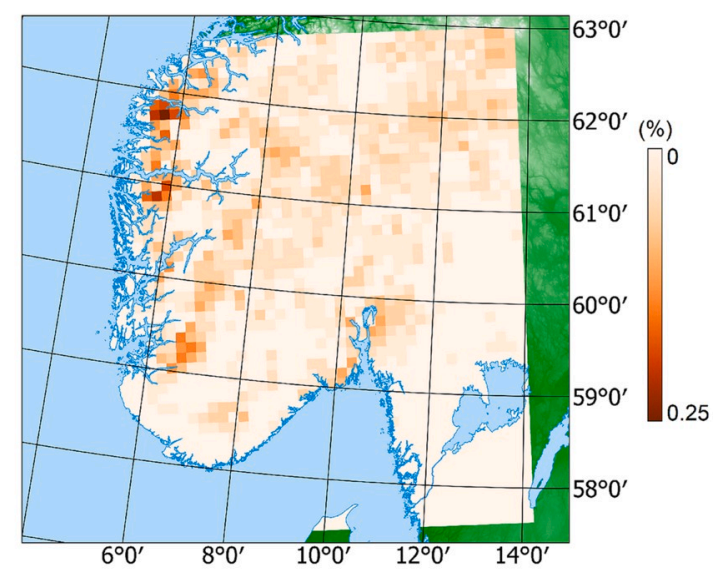

(d)

Fig. 7. Ensemble members with the most extreme compound event occurrence probabilities during the far future. (a) Occurrence probability of SES events in the far future period 2070-2099 calculated with the single member number 3 of the CRCM5-LE and applying $P_{98, \text { ref }}$. (b) Occurrence probability of SES events in the far future period 2070-2099 calculated with the single member number 11 of the CRCM5-LE and applying $P_{98, r e f}$. (c) Occurrence probability of ROS events in the far future period 2070-2099 calculated with the single member number 21 of the CRCM5-LE and applying $P_{98, r e f}$. (d) Occurrence probability of ROS events in the far future period 2070-2099 calculated with the single member number 48 of the CRCM5-LE and applying $P_{98, \text { ref }}$.
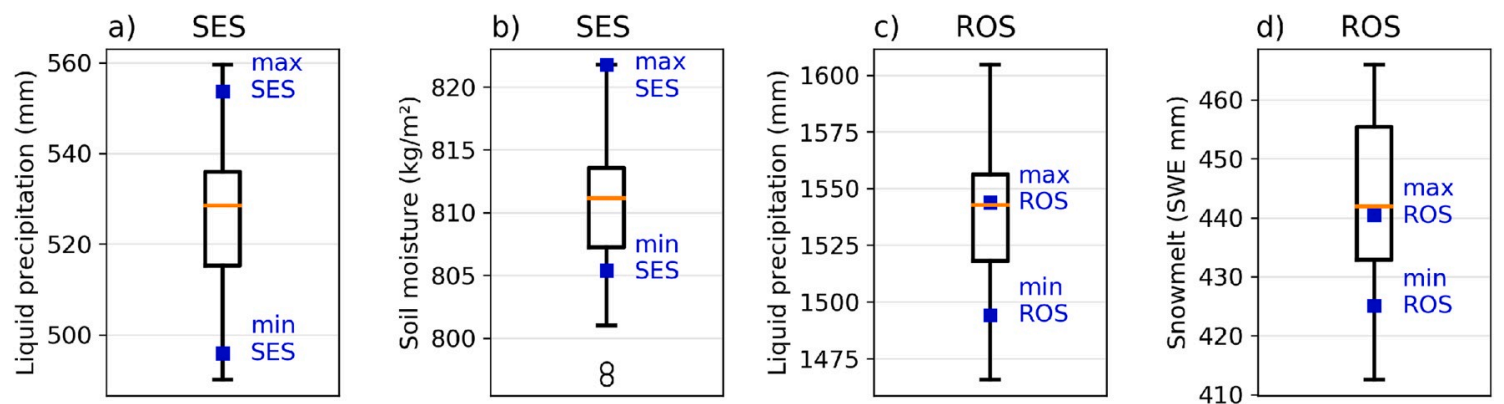

Fig. 8. Areal mean of (a) liquid precipitation and (b) soil moisture during June to September of the far future period (2070-2099) and areal mean of (c) liquid precipitation and (d) snowmelt of the far future period (2070-2099). The boxplots show the range over the 50 members of the CRCM5-LE, whereby the two members with maximum/minimum SES (a,b) and ROS (c,d) occurrence probability, respectively (Fig. 7), are marked as blue squares. The whiskers extend up to a maximum of one and a half times the interquartile range, and all values beyond this range are regarded as outliers (marked as a black circle). (For interpretation of the references to colour in this figure legend, the reader is referred to the Web version of this article.)

introduced in this study, whereas flood-causing SES events are included in the category of rainfall-driven events, but represent only a subset of these events.

Therefore, we can only compare the impact of climate change on the two driving processes to the outcome of other studies. Generally, soil moisture in Norway is expected to decrease until 2100 (Hanssen-Bauer et al., 2015). For the Glomma catchment, which covers big parts of southeastern Norway, soil moisture during 15 May - 15 October is found 
to decrease moderately until 2070-2099, whereby precipitation stays on a similar level (Wong et al., 2011). This experiment was carried out using two different GCMs (ECHAM4 and HadCM3) under the Special Report on Emissions Scenarios (SRES) A2 and B2. The change of rainfall totals during June, July and August over southern Norway is estimated to be between $-5 \%$ and $+15 \%$ within the EURO-CORDEX ensemble under the RCP 8.5 scenario, whereby heavy precipitation is found to increase by $15-25 \%$ (Jacob et al., 2014). These findings regarding soil moisture and precipitation during summer are consistent with the trends discovered in this study.

Regarding the change of ROS event frequency until the far future under RCP 8.5, similar results have been found for other mountainous regions, for instance by Musselman et al. (2018) for western North America. They discovered a significant decrease of ROS event frequency at coastal areas and lower elevations due to snowpack declines. At higher elevations with seasonally persisting snowcover, ROS is found to become more frequent due to a shift from snowfall to rain. Though, their study applies lower thresholds to define ROS events with rainfall greater than $10 \mathrm{~mm} / \mathrm{d}$ and snowmelt greater than $2 \mathrm{~mm} / \mathrm{d}$. Benestad and Haugen (2007) investigated the occurrence of heavy rainfall together with snowmelt in Norway based on $50 \mathrm{~km}$ resolution HIRHAM simulations from 1980 to 1999 and 2030-2049. They focused only on spring time temperature and precipitation and assumed the snow amount to be constant between the two time periods. They found that spring time floods due to concurrent rainfall and snowmelt will increase in the future because of rising temperatures and increasing spring-time precipitation. We also find rising temperatures and precipitation during spring, but our findings regarding ROS events challenge the results of Benestad and Haugen (2007) since a stable surface snow amount is an unrealistic assumption with continuous warming. In the CRCM5-LE, the mean snow surface amount averaged over the study area until 2070-2099 decreases by $59.2 \%$ in comparison to $1980-2009$ for the median of the 50 ensemble members.

Also, Pall et al. (2019) find a negative trend of ROS event frequency in historical observational data (1961-2010), whereby Vormoor et al. (2016) state that the importance of snowmelt as flood driver decreased between 1962 and 2012. This trend is found to continue within the CRCM5-LE simulations, as the areal average of the ratio of $P_{98}$ of snowmelt divided by $P_{98}$ of liquid precipitation almost decreases to half (Fig. 9). Several hydrological studies report the decreasing importance of snowmelt as flood driver in the far future as well, whereas increasing rainfall totals and intensities lead to higher flood magnitudes in rainfall-driven catchments (Lawrence and Hisdal, 2011; Madsen et al., 2014; Rojas et al., 2012; Vormoor et al., 2015). Therefore, our findings regarding future trends tie in with the results of these studies on past, present and future climate change induced trends.

In our analysis, the ROS and SES events are defined by the respective meteorological and hydrological drivers exceeding the 98th percentile. Zscheischler et al. (2018) propose that the investigation of compound events should focus on the impact rather than on the drivers, which would mean in our case that the change in frequency, intensity and extent of the floods resulting from ROS and SES events should be assessed. Implementing this focus within the framework of SMILE is a computationally expensive and labor-intensive task. Although out of scope for the present study, within the ClimEx project, it is planned to apply bias adjustment and further spatial downscaling to all 50 members of the climate simulations of the CRCM5-LE in order to run a hydrological impact model over Bavaria and Québec (Leduc et al., 2019).

As with all analyses based on climate simulations, there are uncertainties within this study as well. Generally, the overall uncertainty of climate projections can be addressed to three different sources: (1) scenario uncertainty arising from the fact that future emissions are unknown, (2) model or response uncertainty, as different models yield different climate simulations though driven by the same radiative forcing and (3) internal or natural variability, which is caused by nonlinear dynamical processes intrinsic to the atmosphere (Deser et al., 2012; Hawkins and Sutton, 2009; von Trentini et al., 2019). A SMILE such as the CRCM5-LE does not address scenario or model/response uncertainties as only one set of global circulation model (GCM: CanESM2), regional climate model (RCM: CRCM5) and emission pathway (RCP 8.5) is used (Leduc et al., 2019). Nonetheless, the large ensemble size of 50 members offers a broad database of 50 equally probable climate simulations, which differ only due to the internal variability of the climate system (Deser et al., 2012). This enables a robust estimate of the occurrence probability of very rare events such as compound events under the assumptions of the chosen emission scenario and the model-internal representation of the physical processes within the RCM and GCM. Though one has to keep in mind that the numerical analysis of occurrence probabilities in section 3 is based on the median representing only the center of the ensemble, whereas single members at the edges of the ensemble distribution feature more extreme scenarios.

To better understand the role of internal variability and also extreme events in current climate projections, several SMILE experiments were set up in the last years (Leduc et al., 2019; Aalbers et al., 2018; Addor and Fischer, 2015). They are a particularly powerful tool for the investigation of compound events. Continuous advances in computational speed allow to run an unprecedented size of ensemble members. For instance, the simulations of the Grand Ensemble of the MPI-ESM have

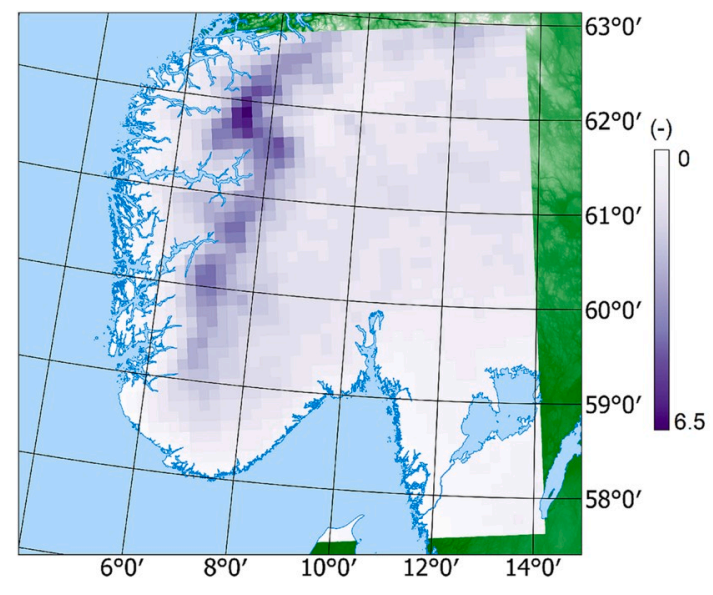

(a)

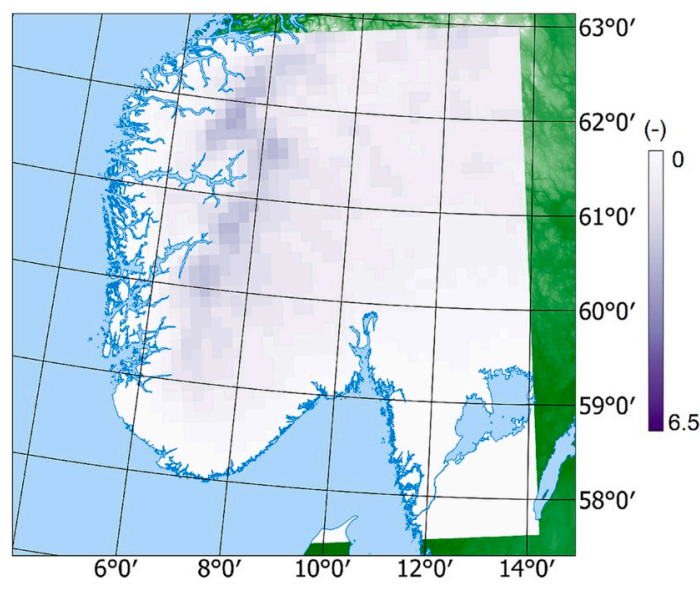

(b)

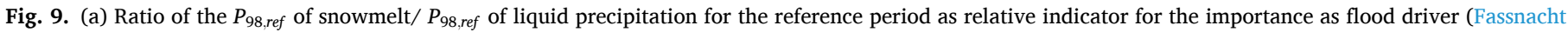
and Records, 2015) (b) Ratio of the $P_{98}$ fut of snowmelt/ $P_{98 \text { fut }}$ of liquid precipitation for the far future period. 
been recently completed, which include 100 ensemble members for the historical time period and four different emission scenarios (Maher et al., 2019). Therefore, scenario uncertainty can be addressed in addition to the internal variability of the 100 members though the broader spatial resolution of GCMs is not suitable for research questions that relate to features of a regional climate and topography (Giorgi et al., 2016; Prein et al., 2016). The dynamical downscaling of the CanESM2 runs by CRCM5-LE with a final resolution of $0.11^{\circ}$ allows a representation of the topography to map mesoscale processes such as orographic precipitation. Especially for the complex topography and different precipitation types over Scandinavia, Heikkilä et al. (2011) and Mayer et al. (2015) emphasize the value added by dynamical downscaling and spatial resolutions of $10 \mathrm{~km}$ and $8 \mathrm{~km}$, respectively. Though, even higher resolutions are recommended by Barstad and Caroletti (2013) and Poschlod et al. (2018) to recreate topographical features on a local scale and explicitly resolve convectional processes. Within the CRCM5-LE convection is parameterized as the physical processes leading to shallow convection can only sufficiently be resolved at resolutions of 4 km or less (Prein et al., 2015; Tabari et al., 2016).

\section{Conclusion}

We apply a quantile-based analysis on two compound events (heavy rainfall on saturated soil during summer (SES) and concurrent heavy rainfall and snowmelt (ROS)) in southern Norway using data from the single model initial condition large ensemble CRCM5-LE. This analysis illustrates the impact of a changing climate on the frequency and spatial distribution of those events. The occurrence probability of heavy rainfall events on very moist soil increases by $38 \%$ from 1980 to 2009 to 2070-2099, whereas the frequency of ROS events decreases by $48 \%$ for the whole study area in a high emission scenario (RCP 8.5). Applying a regional climate model large ensemble with $0.11^{\circ}$ resolution enables the representation of topographical features and investigation of (hydro-) meteorological processes at finer spatial scales than are typically available in global climate models. Hence, spatial patterns and inhomogeneity relating to regional features and processes could be mapped. The regions with high occurrence probability for SES events are located at the Norwegian west coast. Until 2070-2099, these regions expand towards the inner country, whereby the zone with the highest probability is found in the northwest. Despite the strong decrease in ROS event probability over most of the study region due to a reduction in snowfall, there are still areas of high event frequency in the far future. These areas are located mainly on the western flanks of the Scandinavian Mountains, but also at the northwestern coast and around the Oslofjord. The importance of these three drivers of compound floods will shift towards a flood regime less governed by snowmelt, but increasingly triggered by heavy rainfall and saturation excess. Using a large ensemble with 50 members leads to a sufficiently high number of events with very rare occurrence probabilities. Therefore, the analysis results in statistically robust estimations of event probabilities and alterations of these probabilities due to climate change. We show that for single ensemble members, the occurrence probabilities of especially SES events, but also ROS events vary greatly. We attribute this variation to the variability in the timing of the co-occurrence of the contributing processes, which is found to be governed by the internal variability of the climate system. Therefore, a large ensemble size is required to assess the occurrence probability. A similar approach can be applied to examine other types of compound events and how climate change affects their occurrence.

\section{Declaration of competing interest}

The authors declare that they have no known competing financial interests or personal relationships that could have appeared to influence the work reported in this paper.

\section{CRediT authorship contribution statement}

Benjamin Poschlod: Conceptualization, Methodology, Formal analysis, Software, Visualization, Writing - original draft, Writing - review \& editing. Jakob Zscheischler: Writing - review \& editing, Methodology, Funding acquisition. Jana Sillmann: Writing - review \& editing, Conceptualization, Project administration. Raul R. Wood: Writing - review \& editing, Resources. Ralf Ludwig: Writing - review \& editing, Conceptualization, Supervision, Funding acquisition.

\section{Acknowledgement}

We thank all members of the ClimEx project working group for their contributions to produce and analyze the CanESM2-LE and CRCM5-LE. The ClimEx project is funded by the Bavarian State Ministry of the Environment and Consumer Protection. The CRCM5 was developed by the ESCER centre of Université du Québec a Montréal (UQAM; http: //www.escer.uqam.ca) in collaboration with Environment and Climate Change Canada. We thank the Canadian Centre for Climate Modelling and Analysis (CCCma) for executing and making available the CanESM2 Large Ensemble simulations used in this study, and the Canadian Sea Ice and Snow Evolution (CanSISE) Network for proposing the simulations. Computations with the CRCM5 for the ClimEx project were made on the SuperMUC supercomputer at Leibniz Supercomputing Centre (LRZ) of the Bavarian Academy of Sciences and Humanities. The operation of this supercomputer is funded via the Gauss Centre for Supercomputing (GCS) by the German Federal Ministry of Education and Research and the Bavarian State Ministry of Education, Science and the Arts. Additionally, we acknowledge the European COST Action DAMOCLES (CA17109) which supported a Short-Term Scientific Mission of BP at CICERO in Oslo, which contributed significantly to the conception of this study. JZ acknowledges funding from the Swiss National Science Foundation (Ambizione grant 179876). JS is supported by the Norwegian Research Council funded project TWEX (Grant nr. 255037).

\section{Appendix A. Supplementary data}

Supplementary data to this article can be found online at https://doi. org/10.1016/j.wace.2020.100253.

\section{References}

Aalbers, E.E., Lenderink, G., van Meijgaard, E., van den Hurk, B.J.J.M., 2018. Local-scale changes in mean and heavy precipitation in western Europe, climate change or internal variability? Clim. Dynam. 50, 4745-4766. https://doi.org/10.1007/s00382017-3901-9.

Addor, N., Fischer, E.M., 2015. The influence of natural variability and interpolation errors on bias characterization in RCM simulations. J. Geophys. Res.: Atmosphere 120, 10180-10195. https://doi.org/10.1002/2014JD022824.

Barstad, I., Caroletti, G., 2013. Orographic precipitation across an island in southern Norway: model evaluation of time-step precipitation. Q. J. R. Meteorol. Soc. 139, 1555-1565. https://doi.org/10.1002/qj.2067.

Bartlett, P.A., Harry McCaughey, J., Lafleur, P.M., Verseghy, D.L., 2003. Modelling evapotranspiration at three boreal forest stands using the CLASS: tests of parameterizations for canopy conductance and soil evaporation. Int. J. Climatol. 23, 427-451. https://doi.org/10.1002/joc.884.

Bartlett, P.A., MacKay, M.D., Verseghy, D.L., 2006. Modified snow algorithms in the Canadian land surface scheme: model runs and sensitivity analysis at three boreal forest stands. Atmos.-Ocean 44, 207-222. https://doi.org/10.3137/ao.440301.

Benestad, R.E., Haugen, J.E., 2007. On complex extremes: flood hazards and combined high spring-time precipitation and temperature in Norway. Climatic Change 85, 381-406. https://doi.org/10.1007/s10584-007-9263-2.

Benjamini, Y., Hochberg, Y., 1995. Controlling the false discovery rate - a practical and powerful approach to multiple testing. J. Roy. Stat. Soc. B 57, 289-300. https://doi. org/10.2307/2346101.

Berghuijs, W.R., Harrigan, S., Molnar, P., Slater, L.J., Kirchner, J.W., 2019. The relative importance of different flood-generating mechanisms across Europe. Water Resour. Res. 55, 4582-4593. https://doi.org/10.1029/2019WR024841.

Bevacqua, E., Maraun, D., Hobæk Haff, I., Widmann, M., Vrac, M., 2017. Multivariate statistical modelling of compound events via pair-copula constructions: analysis of floods in Ravenna (Italy). Hydrol. Earth Syst. Sci. 21, 2701-2723. https://doi.org/ 10.5194/hess-21-2701-2017. 
Bevacqua, E., Maraun, D., Vousdoukas, M., Voukouvalas, E., Vrac, M., Mentaschi, L., Widmann, M., 2019. Higher potential compound flood risk in northern Europe under anthropogenic climate change. Sci. Adv. 5 https://doi.org/10.1126/sciadv. aaw5531.

Brown, R., Bartlett, P., MacKay, M., Verseghy, D., 2006. Evaluation of snow cover in CLASS for SnowMIP. Atmos.-Ocean 44, 223-238. https://doi.org/10.3137/ ao. 440302 .

Cohen, J., Ye, H., Jones, J., 2015. Trends and variability in rain-on-snow events. Geophys. Res. Lett. 42, 7115-7122. https://doi.org/10.1002/2015GL065320.

Dee, D.P., Uppala, S.M., Simmons, A.J., Berrisford, P., Poli, P., Kobayashi, S., Andrae, U., Balmaseda, M.A., Balsamo, G., Bauer, P., Bechtold, P., Beljaars, A.C.M., van de Berg, L., Bidlot, J., Bormann, N., Delsol, C., Dragani, R., Fuentes, M., Geer, A.J., Haimberger, L., Healy, S.B., Hersbach, H., Hólm, E.V., Isaksen, L., Kållberg, P., Köhler, M., Matricardi, M., McNally, A.P., Monge-Sanz, B.M., Morcrette, J.J., Park, B.K., Peubey, C., de Rosnay, P., Tavolato, C., Thépaut, J.N., Vitart, F., 2011. The ERA-Interim reanalysis: configuration and performance of the data assimilation system. Q. J. R. Meteorol. Soc. 137, 553-597. https://doi.org/10.1002/qj.828.

Deser, C., Phillips, A., Bourdette, V., Teng, H., 2012. Uncertainty in climate change projections: the role of internal variability. Clim. Dynam. 38, 527-546. https://doi. org/10.1007/s00382-010-0977-x.

Dyrrdal, A.V., Skaugen, T., Stordal, F., Førland, E.J., 2016. Estimating extreme areal precipitation in Norway from a gridded dataset. Hydrol. Sci. J. 61, 483-494. https:// doi.org/10.1080/02626667.2014.947289.

Dyrrdal, A.V., Stordal, F., Lussana, C., 2018. Evaluation of summer precipitation from EURO-CORDEX fine-scale RCM simulations over Norway. Int. J. Climatol. 38, 1661-1677. https://doi.org/10.1002/joc.5287.

Fassnacht, S.R., Records, R.M., 2015. Large snowmelt versus rainfall events in the mountains. J. Geophys. Res.: Atmosphere 120, 2375-2381. https://doi.org/ 10.1002/2014JD022753.

Giorgi, F., Torma, C., Coppola, E., Ban, N., Schär, C., Somot, S., 2016. Enhanced summer convective rainfall at alpine high elevations in response to climate warming. Nat. Geosci. 9, 584-589. https://doi.org/10.1038/ngeo2761.

Gruber, A., Scanlon, T., van der Schalie, R., Wagner, W., Dorigo, W., 2019. Evolution of the ESA CCI Soil Moisture climate data records and their underlying merging methodology. Earth Syst. Sci. Data 11, 717-739. https://doi.org/10.5194/essd-11717-2019.

Hanssen-Bauer, I., Drange, H., Førland, E.J., Roald, L.A., Børsheim, K.Y., Hisdal, H., Mayer, S., Nesje, A., Nilsen, J.E.Ø., Sandven, S., Sandø, A.B., Sorteberg, A., Ådlandsvik, B., 2015. Klima I Norge 2100. Kunnskapsgrunnlag for Klimatilpasning Oppdatert I 2015. Technical Report. Norsk klimaservicesenter, Oslo, Norway.

Hao, Z., Singh, V.P., Hao, F., 2018. Compound extremes in hydroclimatology: a review. Water 10. https://doi.org/10.3390/w10060718.

Hawkins, E., Sutton, R., 2009. The potential to narrow uncertainty in regional climate predictions. Bull. Am. Meteorol. Soc. 90, 1095-1108. https://doi.org/10.1175/ 2009BAMS2607.1.

Heikkilä, U., Sandvik, A., Sorteberg, A., 2011. Dynamical downscaling of ERA-40 in complex terrain using the WRF regional climate model. Clim. Dynam. 37, 1551-1564. https://doi.org/10.1007/s00382-010-0928-6.

van den Hurk, B., van Meijgaard, E., de Valk, P., van Heeringen, K.J., Gooijer, J., 2015 Analysis of a compounding surge and precipitation event in The Netherlands. Environ. Res. Lett. 10, 035001 https://doi.org/10.1088/1748-9326/10/3/035001.

Jacob, D., Petersen, J., Eggert, B., Alias, A., Christensen, O.B., Bouwer, L.M., Braun, A., Colette, A., Déqué, M., Georgievski, G., Georgopoulou, E., Gobiet, A., Menut, L., Nikulin, G., Haensler, A., Hempelmann, N., Jones, C., Keuler, K., Kovats, S., Kröner, N., Kotlarski, S., Kriegsmann, A., Martin, E., van Meijgaard, E., Moseley, C., Pfeifer, S., Preuschmann, S., Radermacher, C., Radtke, K., Rechid, D., Rounsevell, M., Samuelsson, P., Somot, S., Soussana, J.F., Teichmann, C., Valentini, R., Vautard, R., Weber, B., Yiou, P., 2014. EURO-CORDEX: new highresolution climate change projections for European impact research. Reg. Environ. Change 14, 563-578. https://doi.org/10.1007/s10113-013-0499-2.

Khanal, S., Lutz, A.F., Immerzeel, W.W., Vries, H.d., Wanders, N., Hurk, B.v.d., 2019. The impact of meteorological and hydrological memory on compound peak flows in the Rhine river basin. Atmosphere 10. https://doi.org/10.3390/atmos10040171.

Kochendorfer, J., Rasmussen, R., Wolff, M., Baker, B., Hall, M.E., Meyers, T., Landolt, S., Jachcik, A., Isaksen, K., Brækkan, R., Leeper, R., 2017. The quantification and correction of wind-induced precipitation measurement errors. Hydrol. Earth Syst. Sci. 21, 1973-1989. https://doi.org/10.5194/hess-21-1973-2017.

Kotlarski, S., Keuler, K., Christensen, O.B., Colette, A., Déqué, M., Gobiet, A., Goergen, K., Jacob, D., Lüthi, D., van Meijgaard, E., Nikulin, G., Schär, C., Teichmann, C., Vautard, R., Warrach-Sagi, K., Wulfmeyer, V., 2014. Regional climate modeling on European scales: a joint standard evaluation of the EUROCORDEX RCM ensemble. Geosci. Model Dev. (GMD) 7, 1297-1333. https://doi.org/ 10.5194/gmd-7-1297-2014.

Krøgli, I.K., Devoli, G., Colleuille, H., Boje, S., Sund, M., Engen, I.K., 2018. The Norwegian forecasting and warning service for rainfall- and snowmelt-induced landslides. Nat. Hazards Earth Syst. Sci. 18, 1427-1450. https://doi.org/10.5194/ nhess-18-1427-2018.

Lawrence, D., Hisdal, H., 2011. Hydrological Projections for Floods in Norway under a Future Climate. Technical Report 5. Norwegian Water Resources and Energy Directorate, Oslo, Norway.

Leduc, M., Mailhot, A., Frigon, A., Martel, J.L., Ludwig, R., Brietzke, G.B., Giguère, M., Brissette, F., Turcotte, R., Braun, M., Scinocca, J., 2019. The ClimEx project: a 50member ensemble of climate change projections at 12-km resolution over Europe and northeastern north America with the Canadian regional climate model (CRCM5). J. Appl. Meteorol. Climatol. 58, 663-693. https://doi.org/10.1175/ JAMC-D-18-0021.1.
Leonard, M., Westra, S., Phatak, A., Lambert, M., van den Hurk, B., McInnes, K., Risbey, J., Schuster, S., Jakob, D., Stafford-Smith, M., 2014. A compound event framework for understanding extreme impacts. Wiley Interdiscipl. Rev.: Clim. Change 5, 113-128. https://doi.org/10.1002/wcc.252.

Lussana, C., Saloranta, T., Skaugen, T., Magnusson, J., Tveito, O.E., Andersen, J., 2018. senorge2 daily precipitation, an observational gridded dataset over Norway from 1957 to the present day. Earth Syst. Sci. Data 10, 235-249. https://doi.org/10.5194/ essd-10-235-2018.

Lussana, C., Tveito, O.E., 2017. senorge2 Dataset. https://doi.org/10.5281/ zenodo.845733.

Madsen, H., Lawrence, D., Lang, M., Martinkova, M., Kjeldsen, T., 2014. Review of trend analysis and climate change projections of extreme precipitation and floods in Europe. J. Hydrol. 519, 3634-3650. https://doi.org/10.1016/j.jhydrol.2014.11.003.

Maher, N., Milinski, S., Suarez-Gutierrez, L., Botzet, M., Dobrynin, M., Kornblueh, L., Kröger, J., Takano, Y., Ghosh, R., Hedemann, C., Li, C., Li, H., Manzini, E., Notz, D., Putrasahan, D., Boysen, L., Claussen, M., Ilyina, T., Olonscheck, D., Raddatz, T., Stevens, B., Marotzke, J., 2019. The Max Planck Institute Grand Ensemble: enabling the exploration of climate system variability. J. Adv. Model. Earth Syst. 11, 2050-2069. https://doi.org/10.1029/2019MS001639.

Maraun, D., Shepherd, T.G., Widmann, M., Zappa, G., Walton, D., Gutierrez, J.M., Hagemann, S., Richter, I., Soares, P.M.M., Hall, A., Mearns, L.O., 2017. Towards process-informed bias correction of climate change simulations. Nat. Clim. Change 7, 764-773. https://doi.org/10.1038/NCLIMATE3418.

Martius, O., Pfahl, S., Chevalier, C., 2016. A global quantification of compound precipitation and wind extremes. Geophys. Res. Lett. 43, 7709-7717. https://doi. org/10.1002/2016GL070017.

Martynov, A., Laprise, R., Sushama, L., Winger, K., Šeparović, L., Dugas, B., 2013. Reanalysis-driven climate simulation over CORDEX North America domain using the Canadian Regional Climate Model, version 5: model performance evaluation. Clim. Dynam. 41, 2973-3005. https://doi.org/10.1007/s00382-013-1778-9.

Masson, V., Champeaux, J.L., Chauvin, F., Meriguet, C., Lacaze, R., 2003. A global database of land surface parameters at $1-\mathrm{km}$ resolution in meteorological and climate models. J. Clim. 16, 1261-1282. https://doi.org/10.1175/1520-0442 16.9.1261.

Mayer, S., Fox Maule, C., Sobolowski, S., Christensen, O., Sørup, H., Sunyer, M., Arnbjerg-Nielsen, K., Barstad, I., 2015. Identifying added value in high-resolution climate simulations over Scandinavia. Tellus 67. https://doi.org/10.3402/tellusa. v67.24941.

McCabe, G.J., Clark, M.P., Hay, L.E., 2007. Rain-on-snow events in the western United States. Bull. Am. Meteorol. Soc. 88, 319-328. https://doi.org/10.1175/BAMS-88-3319.

Merz, R., Blöschl, G., 2003. A process typology of regional floods. Water Resour. Res. 39 https://doi.org/10.1029/2002WR001952.

Musselman, K., Lehner, F., Ikeda, K., Clark, M., Prein, A., Liu, C., Barlage, M., Rasmussen, R., 2018. Projected increases and shifts in rain-on-snow flood risk over western north America. Nat. Clim. Change 8. https://doi.org/10.1038/s41558-0180236-4.

Naz, B.S., Kurtz, W., Montzka, C., Sharples, W., Goergen, K., Keune, J., Gao, H., Springer, A., Hendricks Franssen, H.J., Kollet, S., 2019. Improving soil moisture and runoff simulations at $3 \mathrm{~km}$ over Europe using land surface data assimilation. Hydrol. Earth Syst. Sci. 23, 277-301. https://doi.org/10.5194/hess-23-277-2019.

Pall, P., Tallaksen, L.M., Stordal, F., 2019. A climatology of rain-on-snow events for Norway. J. Clim. https://doi.org/10.1175/JCLI-D-18-0529.1.

Pan, Wang, Liu, Zhao, Fu, 2019. Global surface soil moisture dynamics in 1979 - 2016 observed from ESA CCI SM dataset. Water 11, 883. https://doi.org/10.3390/ w11050883.

Poschlod, B., Hodnebrog, Ø., Wood, R.R., Alterskjær, K., Ludwig, R., Myhre, G., Sillmann, J., 2018. Comparison and evaluation of statistical rainfall disaggregation and high-resolution dynamical downscaling over complex terrain. J. Hydrometeorol. 19, 1973-1982. https://doi.org/10.1175/JHM-D-18-0132.1.

Prein, A., Langhans, W., Fosser, G., Ferrone, A., Ban, N., Goergen, K., Keller, M., Tölle, M., Gutjahr, O., Feser, F., Brisson, E., Kollet, S., Schmidli, J., van Lipzig, P.M. N., Leung, L., 2015. A review on regional convection-permitting climate modeling: demonstrations, prospects, and challenges: convection-permitting climate modeling. Rev. Geophys. 53 https://doi.org/10.1002/2014RG000475.

Prein, A.F., Gobiet, A., Truhetz, H., Keuler, K., Goergen, K., Teichmann, C., Fox Maule, C., van Meijgaard, E., Déqué, M., Nikulin, G., Vautard, R., Colette, A., Kjellström, E., Jacob, D., 2016. Precipitation in the EURO-CORDEX $0.11^{\circ}$ and $0.44^{\circ}$ simulations: high resolution, high benefits? Clim. Dynam. 46, 383-412. https://doi. org/10.1007/s00382-015-2589-y.

Putkonen, J., Roe, G., 2003. Rain-on-snow events impact soil temperatures and affect ungulate survival. Geophys. Res. Lett. 30 https://doi.org/10.1029/2002GL016326.

Roe, G.H., 2005. Orographic precipitation. Annu. Rev. Earth Planet Sci. 33, 645-671. https://doi.org/10.1146/annurev.earth.33.092203.122541.

Rojas, R., Feyen, L., Bianchi, A., Dosio, A., 2012. Assessment of future flood hazard in Europe using a large ensemble of bias-corrected regional climate simulations. J. Geophys. Res.: Atmosphere 117. https://doi.org/10.1029/2012JD017461.

Rössler, O., Froidevaux, P., Börst, U., Rickli, R., Martius, O., Weingartner, R., 2014. Retrospective analysis of a nonforecasted rain-on-snow flood in the Alps - a matter of model limitations or unpredictable nature? Hydrol. Earth Syst. Sci. 18, 2265-2285. https://doi.org/10.5194/hess-18-2265-2014.

Rutter, N., Essery, R., Pomeroy, J., Altimir, N., Andreadis, K., Baker, I., Barr, A., Bartlett, P., Boone, A., Deng, H., Douville, H., Dutra, E., Elder, K., Ellis, C., Feng, X., Gelfan, A., Goodbody, A., Gusev, Y., Gustafsson, D., Hellström, R., Hirabayashi, Y., Hirota, T., Jonas, T., Koren, V., Kuragina, A., Lettenmaier, D., Li, W.P., Luce, C., Martin, E., Nasonova, O., Pumpanen, J., Pyles, R.D., Samuelsson, P., Sandells, M., 
Schädler, G., Shmakin, A., Smirnova, T.G., Stähli, M., Stöckli, R., Strasser, U., Su, H., Suzuki, K., Takata, K., Tanaka, K., Thompson, E., Vesala, T., Viterbo, P. Wiltshire, A., Xia, K., Xue, Y., Yamazaki, T., 2009. Evaluation of forest snow processes models (snowmip2). J. Geophys. Res.: Atmosphere 114. https://doi.org/ 10.1029/2008JD011063.

Sandvik, M.I., Sorteberg, A., Rasmussen, R., 2018. Sensitivity of historical orographically enhanced extreme precipitation events to idealized temperature perturbations. Clim. Dynam. 50, 143-157. https://doi.org/10.1007/s00382-017-3593-1.

Schär, C., Ban, N., Fischer, E.M., Rajczak, J., Schmidli, J., Frei, C., Giorgi, F., Karl, T.R., Kendon, E.J., Klein Tank, A.M.G., O'Gorman, P.A., Sillmann, J., Zhang, X., Zwiers, F. W., 2016. Percentile indices for assessing changes in heavy precipitation events. Climatic Change 137, 201-216. https://doi.org/10.1007/s10584-016-1669-2.

Seneviratne, S., Nicholls, N., Easterling, D., Goodess, C., Kanae, S., Kossin, J., Luo, Y., Marengo, J., Mcinnes, K., Rahimi, M., Reichstein, M., Sorteberg, A., Vera, C., Zhang, X., 2012. Changes in climate extremes and their impacts on the natural physical environment. In: Field, C., Barros, V., Stocker, T.F., Qin, D., Dokken, D.J., Ebi, K.L., Mastrandrea, M.D., Mach, K.J., Plattner, G.K., Allen, S.K., Tignor, M., Midgley, P.M. (Eds.), Managing the Risks of Extreme Events and Disasters to Advance Climate Change Adaptation. A Special Report of Working Groups I and II of the Intergovernmental Panel on Climate Change. Cambridge University Press, Cambridge, pp. 109-230.

Serinaldi, F., 2013. An uncertain journey around the tails of multivariate hydrological distributions. Water Resour. Res. 49, 6527-6547. https://doi.org/10.1002/ wrcr.20531.

Sturm, M., Holmgren, J., König, M., Morris, K., 1997. The thermal conductivity of seasonal snow. J. Glaciol. 43, 26-41. https://doi.org/10.3189/ S0022143000002781.

Tabari, H., De Troch, R., Giot, O., Hamdi, R., Termonia, P., Saeed, S., Brisson, E., Van Lipzig, N., Willems, P., 2016. Local impact analysis of climate change on precipitation extremes: are high-resolution climate models needed for realistic simulations? Hydrol. Earth Syst. Sci. 20, 3843-3857. https://doi.org/10.5194/hess20-3843-2016.

Tjelta, T., Mamen, J., 2014. Climate trends and variability of rain rate derived from longterm measurements in Norway. Radio Sci. 49, 788-797. https://doi.org/10.1002/ 2014RS005477.

von Trentini, F., Leduc, M., Ludwig, R., 2019. Assessing natural variability in RCM signals: comparison of a multi model EURO-CORDEX ensemble with a 50-member single model large ensemble. Clim. Dynam. 53, 1963-1979. https://doi.org/ 10.1007/s00382-019-04755-8.

Ventura, V., Paciorek, C.J., Risbey, J.S., 2004. Controlling the proportion of falsely rejected hypotheses when conducting multiple tests with climatological data. J. Clim. 17, 4343-4356. https://doi.org/10.1175/3199.1.

Verseghy, D.L., 1991. CLASS - a Canadian land surface scheme for GCMS. I. Soil model. Int. J. Climatol. 11, 111-133. https://doi.org/10.1002/joc.3370110202.
Verseghy, D.L., 2009. CLASS - the Canadian Land Surface Scheme (Version 3.4) Technical Documentation (Version 1.1). Technical Report. Climate Research Division, Science and Technology Branch, Environment Canada, Toronto, Ontario, Canada.

Vormoor, K., Lawrence, D., Heistermann, M., Bronstert, A., 2015. Climate change impacts on the seasonality and generation processes of floods - projections and uncertainties for catchments with mixed snowmelt/rainfall regimes. Hydrol. Earth Syst. Sci. 19, 913-931. https://doi.org/10.5194/hess-19-913-2015.

Vormoor, K., Lawrence, D., Schlichting, L., Wilson, D., Wong, W.K., 2016. Evidence for changes in the magnitude and frequency of observed rainfall vs. snowmelt driven floods in Norway. J. Hydrol. 538, 33-48. https://doi.org/10.1016/j. jhydrol.2016.03.066.

Wahl, T., Jain, S., Bender, J., Meyers, S.D., Luther, M.E., 2015. Increasing risk of compound flooding from storm surge and rainfall for major US cities. Nat. Clim. Change 5, 1093.

Westra, S., Fowler, H.J., Evans, J.P., Alexander, L.V., Berg, P., Johnson, F., Kendon, E.J., Lenderink, G., Roberts, N.M., 2014. Future changes to the intensity and frequency of short-duration extreme rainfall. Rev. Geophys. 52, 522-555. https://doi.org/ 10.1002/2014RG000464.

Wilks, D.S., 2016. "The stippling shows statistically significant grid points": How research results are routinely overstated and overinterpreted, and what to do about it. Bull. Am. Meteorol. Soc. 97, 2263-2273. https://doi.org/10.1175/BAMS-D-1500267.1.

Wong, W.K., Beldring, S., Engen-Skaugen, T., Haddeland, I., Hisdal, H., 2011. Climate change effects on spatiotemporal patterns of hydroclimatological summer droughts in Norway. J. Hydrometeorol. 12, 1205-1220. https://doi.org/10.1175/ 2011JHM1357.1.

Zhang, X., Alexander, L., Hegerl, G.C., Jones, P., Klein Tank, A., Peterson, T.C., Trewin, B., Zwiers, F.W., 2011. Indices for monitoring changes in extremes based on daily temperature and precipitation data. Wiley Interdiscipl. Rev.: Clim. Change 2, 851-870. https://doi.org/10.1002/wcc.147.

Zhenghui, X., Fengge, S., Xu, L., Qingcun, Z., Zhenchun, H., Yufu, G., 2003. Applications of a surface runoff model with horton and dunne runoff for VIC. Adv. Atmos. Sci. 20, 165-172. https://doi.org/10.1007/s00376-003-0001-z.

Zhou, P., Liu, Z., 2018. Likelihood of concurrent climate extremes and variations over China. Environ. Res. Lett. 13, 094023 https://doi.org/10.1088/1748-9326/aade9e.

Zscheischler, J., Fischer, E.M., Lange, S., 2019. The effect of univariate bias adjustment on multivariate hazard estimates. Earth Syst. Dynam. 10, 31-43. https://doi.org/ 10.5194/esd-10-31-2019.

Zscheischler, J., Seneviratne, S.I., 2017. Dependence of drivers affects risks associated with compound events. Sci. Adv. 3 https://doi.org/10.1126/sciadv.1700263.

Zscheischler, J., Westra, S., Hurk, B., Seneviratne, S., Ward, P., Pitman, A., AghaKouchak, A., Bresch, D., Leonard, M., Wahl, T., Zhang, X., 2018. Future climate risk from compound events. Nat. Clim. Change 8, 469-477. https://doi.org/ 10.1038/s41558-018-0156-3. 